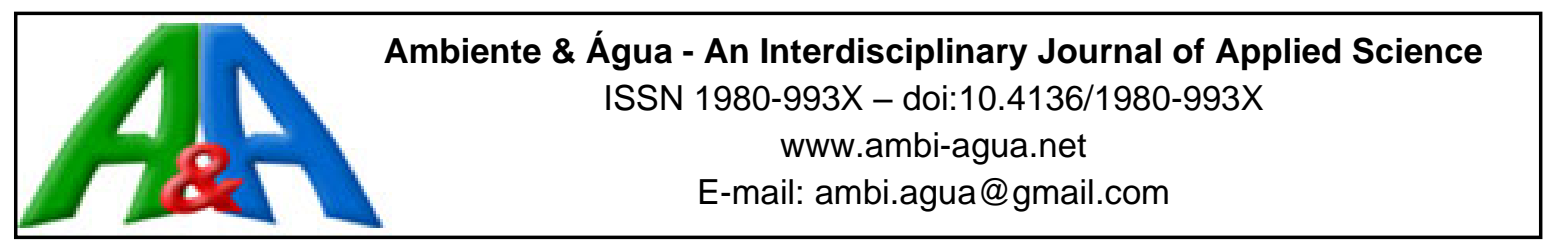

\title{
Seasonal litterfall and nutrients in an Atlantic Forest fragment
}

\author{
ARTICLES doi:10.4136/ambi-agua.2775
}

Received: 23 Jul. 2021; Accepted: 11 Jan. 2022

\begin{abstract}
Diêgo Gomes Júnior ${ }^{1} \mathbb{D}^{-}$; Marcos Vinicius Winckler Caldeira ${ }^{2}$; Sustanis Horn Kunz ${ }^{2}$; William Macedo Delarmelina ${ }^{3}$; Dione Richer Momolli*iD; Elzimar de Oliveira Gonçalves ${ }^{2}$ iD Julia Siqueira Moreau ${ }^{5}$ iD

${ }^{1}$ Gerência Local de Alegre. Instituto de Defesa Agropecuária e Florestal do Espírito Santo (IDAF-ES), Rua Olívio Correia Pedrosa, $n^{\circ}$ 566, CEP: 29500-000, Alegre, ES, Brazil. E-mail: diegogomesj@gmail.com

${ }^{2}$ Departamento de Ciências Florestais e da Madeira. Universidade Federal do Espírito Santo (UFES), Avenida Governador Lindemberg, n 316 , CEP: 29550-000, Jerônimo Monteiro, ES, Brazil.

E-mail: mvwcaldeira@gmail.com, sustanis@gmail.com, elzimarog@yahoo.com.br ${ }^{3}$ Técnico em Florestas. Instituto Federal de Educação, Ciência e Tecnologia do Espírito Santo (IFES), Campus Ibatiba, Avenida 7 de Novembro, n 40, CEP: 29395-000, Ibatiba, ES, Brazil. E-mail: william.delarmelina@ifes.edu.br

${ }^{4}$ Departamento de Engenharia Florestal. Universidade Federal de Santa Maria (UFSM), Avenida Roraima, $\mathrm{n}^{\circ}$ 1000, CEP: 97105-900, Santa Maria, RS, Brazil.

${ }^{5}$ Instituto Federal de Educação, Ciência e Tecnologia do Pará (IFPA), Campus Breves, Rua Antônio Fulgêncio da Silva, s/n, CEP: 68800-000, Breves, PA, Brazil. E-mail: julia.moreau@ifpa.edu.br

*Corresponding author. E-mail: dionemomolli@gmail.com
\end{abstract}

\begin{abstract}
Litter dynamics is one of the fundamental processes for the growth and maintenance of native forest fragments, being considered the main pathway for nutrient cycling in forests. Studies on litter production and nutrient content therefore provide insights that provide a better understanding of nutrient dynamics. This study identifies the seasonality and meteorological conditions that influence the quantity and return of nutrients through litter in an Atlantic Forest fragment. Litter sampling was carried out monthly in 12 permanent plots. Each plot contained 5 littertraps distributed systematically. The litter was classified, and the dry mass and nutrients in the leaves and branches and miscellaneous fractions was quantified. Seasonal behavior was observed, with the highest depositions in the winter season. The average annual production was $6.78 \mathrm{Mg} \mathrm{ha}^{-1}$, with $64.9 \%$ being composed of leaves. The mean annual nutrient intake was 135.1, 115.7, 39.7, 23.5, 17.6 and $4.6 \mathrm{~kg} \mathrm{ha}^{-1}$ for $\mathrm{Ca}, \mathrm{N}, \mathrm{K}, \mathrm{Mg}, \mathrm{S}$ and $\mathrm{P}$, respectively. The meteorological variable precipitation influenced the deposition pattern. The increase in nutrient-use efficiency in the second year compared to the first indicates that plants strategically may be re-translocating relative amounts of their nutrients under water stress conditions.
\end{abstract}

Keywords: ecosystem functions, nutrient cycling, secondary succession.

\section{Sazonalidade da deposição de serapilheira e nutrientes em um fragmento de Floresta Atlântica}

\section{RESUMO}

A dinâmica de serapilheira é um dos processos fundamentais para o crescimento e manutenção de fragmentos florestais nativos, sendo considerada a principal via da ciclagem de 
nutrientes em florestas. Dessa forma, estudos sobre produção de serapilheira e conteúdo de nutrientes fornecem subsídios que proporcionam um melhor entendimento da dinâmica dos nutrientes. O objetivo do estudo foi identificar a sazonalidade e as condições meteorológicas que influenciam na quantifidade e no retorno de nutrientes através da serapilheira em um fragmento de Floresta Atlântica. A amostragem de serapilheira foi realizada mensalmente em 12 parcelas permanentes. Cada parcela continha 5 coletores distribuídos sistematicamente. A serapilheira foi classificada, quantificada a massa seca e nutrientes nas frações folhas e galhos + miscelânea. Foi constatado comportamento sazonal com as maiores deposições na estação do inverno. A produção média anual foi de $6,78 \mathrm{Mg} \mathrm{ha}^{-1}$, sendo $64,9 \%$ composta por folhas. A entrada média de nutrientes anual foi de $135.1,115.7,39.7,23.5,17.6$ e $4.6 \mathrm{~kg} \mathrm{ha}^{-1}$ para $\mathrm{Ca}, \mathrm{N}$, $\mathrm{K}, \mathrm{Mg}, \mathrm{S}$ e $\mathrm{P}$ respectivamente. A variável meteorológica precipitação apresentou influencia no padrão de deposição. $\mathrm{O}$ aumento na eficiência do uso de nutrientes no segundo ano em comparação com o primeiro indica que as plantas estrategicamente podem estar retranslocando quantidades relativas de seus nutrientes sob condições de estresse hídrico.

Palavras-chave: ciclagem dos nutrientes, indicadores ecológicos, sucessão secundária.

\section{INTRODUCTION}

The continued exploitation of natural resources is responsible for forest fragmentation and consequent loss of biodiversity (Fahrig, 2003). Both the fragmentation of forest remnants and the decrease in biodiversity result in a reduction in carbon stock and nutrient cycling capacity (Bello et al., 2015; Wolf et al., 2013). The Atlantic Forest biome is a biodiversity hotspot (Strassburg et al., 2020); however, it has been the most affected in recent decades, with only $12.4 \%$ of the 131 million hectares of native forest remaining. The state of Espírito Santo is fully inserted in this biome; however, only $10.5 \%$ of the original area remains (SOS Mata Atlântica, 2020). The forest cover in the south of the state is formed by small fragments of Seasonal Semideciduous Forest, due to a series of anthropogenic disturbances (Godinho et al., 2013).

The assessment of nutrient cycling is an indicator for the degree of sustainability of ecosystems (Haag, 1985; Balieiro et al., 2004). Nutrient cycling is the process in which the nutrients adsorbed by plants return to the soil through the input and decomposition of plant tissues, where they will be mineralized and made available again to plants (Odum, 1988). This process is of great importance for natural systems, especially in tropical areas, where the soils are highly weathered (Laliberte et al., 2013).

The organic material constituted by leaves, branches, bark and plant reproductive material, which is deposited in the soil via vegetation, is called "litter" (Kramer and Kozlowski, 1960; Fassebender, 1993). Assessment of litter seasonality and nutrient content for two years or more can provide a better understanding of nutrient dynamics across the biogeochemical cycle. This information supports the choice of the most suitable species for the formation and enrichment of the fragments (Caldeira et al., 2008). In addition, monitoring of litterfall has been shown to be a good proxy for estimates of net primary production (NPP) in tropical forests on annual or multiannual scales (Malhi et al., 2011) and the capacity to respond to external disturbances (Oliveira and Lacerda, 1999).

Determining a reference ecosystem is important for defining strategies for monitoring restoration programs (Martins et al., 2012). Investigating the nutrient return through litterfall represents an important indicator for soil fertility in areas in early stages or secondary successions (Martins, 2016; Sanchez and Alvarez-Sanchez, 1995).

Leaves, in quantity and nutrients, are the main litter component for most terrestrial ecosystems (Berg and Laskowski, 2005). The percentages, according to the review carried out by Zhang et al. (2014), range from 64 to $73 \%$ of this component among different forest 
formations in the world. Leaf litter responds to changing weather conditions (Chave et al., 2010; Wagner et al., 2016). In tropical forests, it is observed that long periods with low precipitation promote a reduction in soil moisture and, consequently, an increase in xylem tension. These factors promote stomata closure (Nepstad et al., 2002). Associated with low water availability, lower temperatures are similarly responsible for litter peaks (Lawrence, 2005; Wang et al., 2021).

Based on these reasons, monitoring litter composition and its nutrients is essential for forest fragment restoration strategies. Considering that meteorological variables influence litter seasonality, this study evaluated the deposition and input of nutrients over two years.

\section{MATERIALS AND METHODS}

\subsection{Characterization of the experimental area}

The study area was located in (RPPN) Private Natural Heritage Reserve Fazenda Boa Esperança (IBAMA, 1998) The RPPN is located in the municipality of Cachoeiro de Itapemirim, southern Espírito Santo, at coordinates UTM/SIRGAS2000 268275.48 E and 7707754.70 S (Figure 1). The RPPN has a total area of 517 ha, comprising four forest fragments. The present study, inserted in the Itapemirim River Watershed, was carried out in a forest fragment with an area of 358.86 ha, belonging to the Burarama - Pacotuba - Cafundó ecological corridor. The average altitude of the 12 plots was $110 \mathrm{~m}$, ranging from $91 \mathrm{~m}$ to 160 $\mathrm{m}$. The average slope was $6.7 \%$, ranging from $1 \%$ to $25 \%$.

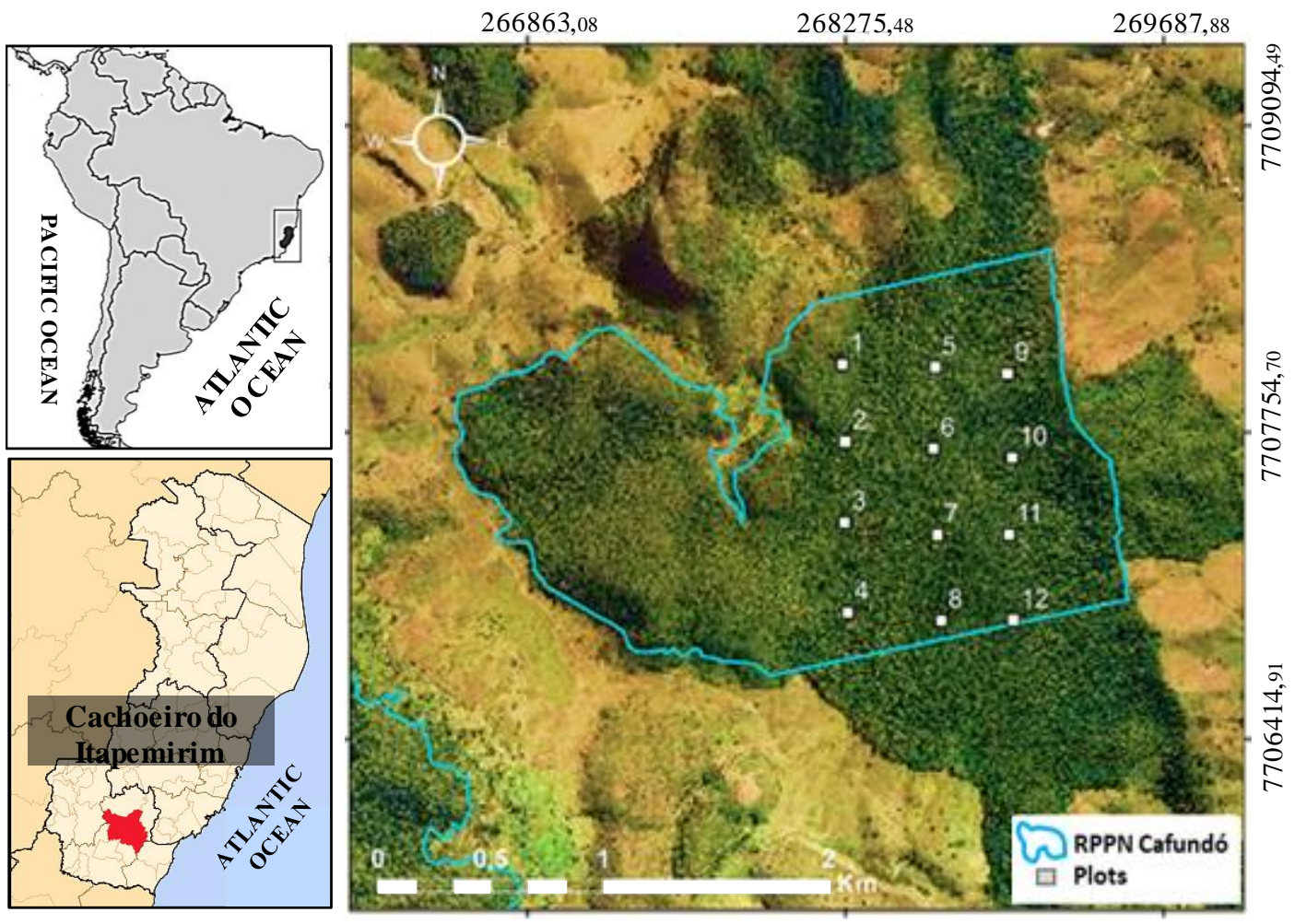

Figure 1. Location of the experiment and plots in the RPPN in an Atlantic Forest fragment in southeastern Brazil.

Source: Delarmelina (2015), adapted by the author.

The vegetation in the present study area is classified as Submontane Seasonal Semideciduous Forest (IBGE, 2012). In a study on the structure of the arboreal component of the area, Archanjo et al. (2012) observed high richness of late secondary species (58\%), low density of early succession groups $(26 \%)$ and pioneers $(0.2 \%)$, indicating that it is a well- 
preserved forest fragment with an advanced stage of succession. The density verified was 1823 plants ha ${ }^{-1}$, with 258 species and 54 families. The five largest families represent $43 \%$ of all species (Fabaceae, Myrtaceae, Euphorbiaceae, Sapotaceae and Rubiaceae). The most common species are: Astronium concinnum, Pseudopiptadenia contorta, Neoraputia alba, Astronium graveolens and Gallesia integrifólia (Delarmelina 2015).

The climate of the region, according to the classification of Köppen, is of the Aw type (tropical with a dry season in winter) (Alvares et al., 2014), with an average temperature of the minimum of the coldest month of $11.8^{\circ} \mathrm{C}$, and the average of the highs of the hottest month of $34^{\circ} \mathrm{C}$ (Pezzopane et al., 2012). According to rainfall characterization maps of Espírito Santo, the annual rainfall in the study area is between 1200 and $1300 \mathrm{~mm}$ (INCAPER, 2017).

Precipitation data, for the study period and for the historical series (1987 - 2016), were obtained from the National Water Agency (ANA) station (02041002), located in the municipality of Castelo - ES, approximately $12 \mathrm{~km}$ away from the study area. The temperature data are from the automatic surface meteorological station of the National Institute of Meteorology (INMET) (Alegre-A617), located in the municipality of Alegre - ES, approximately $26 \mathrm{~km}$ from the studied area. The history of monthly averages for this variable was obtained with data from the same station, for the period of 2006 to 2016, Figure 2.

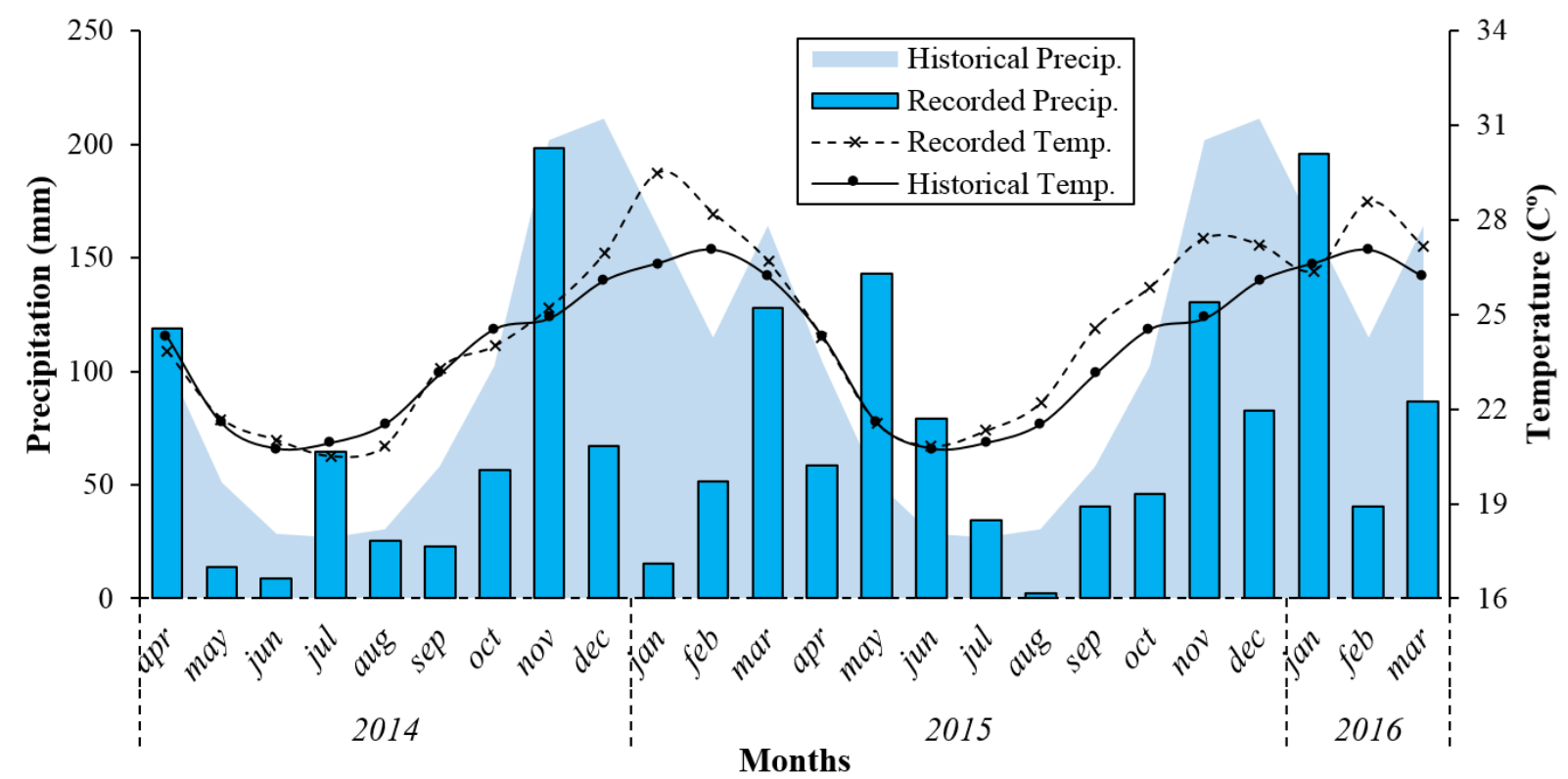

Figure 2. Climatic diagram during the research period and average of the historical series (1987 - 2016) obtained by an automatic station (ANA) located $12 \mathrm{~km}$ away.

The study area has soils of the Planosol, Cambisol and Ferrasol types. To determine the attributes of the soil, the samples were chipped, dried in the shade and sieved ( $2 \mathrm{~mm}$ of mesh), obtaining the fine air-dried soil (TFSA). Later, they were used to determine physical and chemical attributes, according to Embrapa (2011). The sandy textural class was observed in Planosol and Cambisol, while the more clayey texture was observed in Ferrasol. Soil pH ranged from 3.3 to 6.07 and higher acidity was found in Ferrasol type. The contents of $\mathrm{K}, \mathrm{Ca}^{2+}$ and $\mathrm{Mg}^{2+}$, as well as SB and a t were higher in the superficial horizons of the Cambisol and Ferrasol profiles. In general, the soils in the region of the Planosol and Cambisol profiles were more fertile than the soil in the region of the Ferrasol profile, as verified by the higher values of $\mathrm{P}$, SB and V.

\subsection{Litterfall}

The monitoring of litter deposition was carried out monthly from April 2014 to March

Rev. Ambient. Água vol. 17 n. 1, e2775 - Taubaté 2022 
2016. For this, 12 permanent plots with dimensions of $20 \mathrm{~m}$ x $50 \mathrm{~m}$ were demarcated, Figure 1 , totaling an area of $12000 \mathrm{~m}^{2}$. The plots were systematically distributed in the area, 350 meters away from each other.

For the collection of litter, a total of 60 litter traps were installed systematically, 5 littertraps in each plot, with a collector near each vertex and one in the center of the plot. The collectors were made in a square format, with PVC material and $2 \mathrm{~mm}$ nylon mesh, having $0.75 \mathrm{~m}$ on each side (area of $0.5625 \mathrm{~m}^{2}$ ) and $1 \mathrm{~m}$ high from the ground (Scoriza et al., 2012; Castro, 2014).

After collection, the litter was classified into the leaf fractions and the twigs + miscellaneous fractions, represented by twigs with a diameter less than $2 \mathrm{~cm}$, bark, reproductive material and other plant material whose identification was not possible. After classification, the samples were stored in paper bags and dried in an air-circulation oven at $65^{\circ} \mathrm{C}$. When they reached constant weight, the material was weighed on an analytical balance $(0.001 \mathrm{~g})$ to obtain the dry mass. With the dry mass data, the fractions and the total litter deposited per unit area $\left(\mathrm{kg} \mathrm{ha}^{-1}\right)$ were calculated. The samples of each monthly fraction were homogenized to obtain three representative monthly samples of each fraction. They were shredded in a Willey-type mill with a 1-mm mesh (20 mesh) sieve. Subsequently, they were sent for chemical analysis of the plant material.

\subsection{Chemical analysis}

The chemical analyses of the macronutrient ( $\mathrm{N}, \mathrm{P}, \mathrm{K}, \mathrm{Ca}, \mathrm{Mg}$ and $\mathrm{S}$ ) concentrations of the litter were carried out at FULLIN - Laboratory for Agronomic, Environmental Analysis and Preparation of Chemical Solutions. Nitrogen was extracted by sulfuric digestion and determined in a Kjeldahl distiller, while the other nutrients were extracted by nitro perchloric digestion, with phosphorus and sulfur being determined by optical spectrophotometry, and potassium, calcium and magnesium determined by atomic absorption spectrophotometry (Tedesco et al., 1995).

The values of nutrient utilization efficiency (NUE) were obtained according to a calculation proposed by Vitousek (1982) (Equation 1) using the relationship between the amount of dry biomass of each component and the amount of nutrients stored in the respective biomass.

$$
\mathrm{NUE}=\frac{\text { Dry mass }\left(\mathrm{kgha^{-1 }}\right)}{\text { Nutrient }\left(\mathrm{kg} \mathrm{ha} \mathrm{a}^{-1}\right)}
$$

The amount of macronutrients $\left(\mathrm{kg} \mathrm{ha}^{-1} \mathrm{month}^{-1}\right)$ of the litter was obtained by multiplying the dry mass $\left(\mathrm{kg} \mathrm{ha}^{-1}\right.$ month $\left.^{-1}\right)$ by the nutrient concentration $\left(\mathrm{g} \mathrm{kg}^{-1}\right)$, according to Equation 2 (Cuevas and Medina, 1986).

$$
\mathrm{AN}=[\text { Nutrient }] \times \mathrm{DM}
$$

Where:

$\mathrm{AN}=$ Amount of nutrients $\left(\mathrm{kg} \mathrm{ha}^{-1}\right.$ monthly $\left.^{-1}\right)$;

[Nutrient] $=$ Nutrient concentration $\left(\mathrm{g} \mathrm{kg}^{-1}\right)$;

$\mathrm{DM}=$ Dry mass $\left(\mathrm{kg} \mathrm{ha} \mathrm{mês}^{-1}\right)$.

\subsection{Statistics and Data Analysis}

Data analysis was performed using the R software (R CORE TEAM, 2016). For the amount of litter, the 12 plots represented the repetitions while the seasons were the treatments: summer (January, February and March), autumn (April, May and June), winter (July, August, and September) and spring (October, November, and December). A statistically significant difference was verified by applying the ANOVA Test ( $p$-value $\leq 0.05$ ). 
The analysis of the influence of meteorological variables on litterfall was verified through Spearman's correlation between the amounts of litterfall dry mass and the meteorological elements (air temperature, precipitation and evapotranspiration) for the period of this study.

\section{RESULTS AND DISCUSSION}

\subsection{Amount of litter}

Litter deposition over 2 years was $8806 \mathrm{~kg} \mathrm{ha}^{-1}$ or $4403 \mathrm{~kg} \mathrm{ha}^{-1}$ year $^{-1}$. The leaf component represented $64.9 \%$ of the total, while twigs + miscellaneous accounted for $35.1 \%$ Figure 3 .

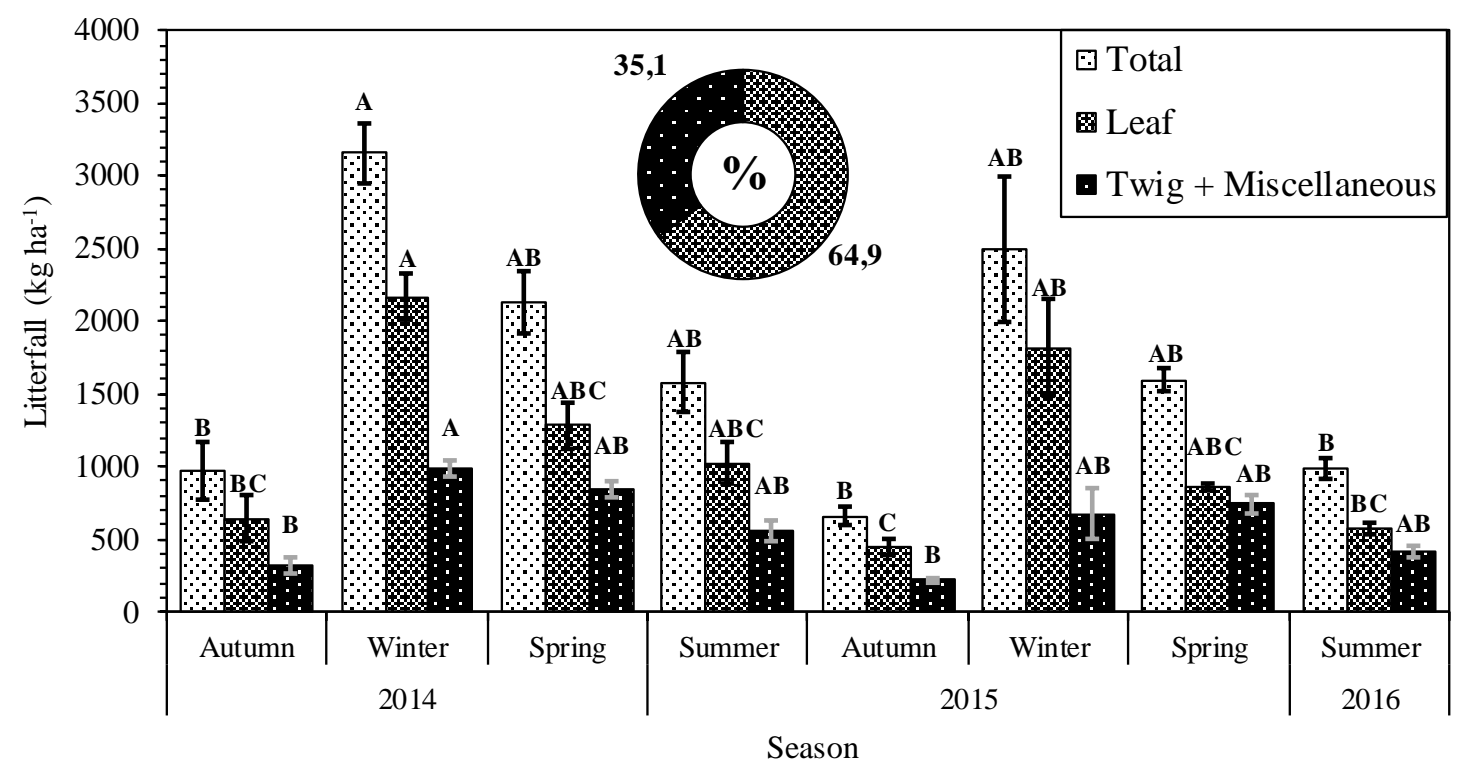

Figure 3. Seasonal litter falls over two years in different components in an Atlantic Forest fragment located in southeastern Brazil.

Different letters between seasons for the same fraction represent a statistical difference $(\mathrm{p}<$ 0.05). Bars: Confidence Interval (95\%).

When analyzing the deposition over the seasons, it is observed that the two winter seasons represented the largest contributions, being that the winter of 2014 differed statistically from the autumn of 2014 and 2015, in addition to the summer of 2016 for the total litter fall. The leaf fraction is responsible for the variation in the total litter contribution between the seasons of the year, since this fraction had, in all seasons, a greater mass contribution than the twigs + miscellaneous fractions.

Referring to litterfall composition, it is observed that there was important variation along the seasons. It is also observed that in the spring 2014 and 2015 and summer 2016 seasons, the leaf component represented $60 \%$ or less of the total litter fall. These seasons recorded rainfall of around $300 \mathrm{~mm}$.

During the winter seasons, there was an increase in the leaf fraction, representing 69 and $73 \%$ of the total litterfall. The explanation for the result can be attributed to the decrease in precipitation during the winter, less than $100 \mathrm{~mm}$. Through the Spearman correlation between meteorological variables and litter components, it is possible to conclude that these environmental variables influence the litter deposition pattern throughout the seasons. Spearman's statistics showed that there was a significant correlation between litterfall and the accumulated precipitation of 3,4 and 5 months. The leaf fraction responded better to precipitation while twigs + miscellaneous did not show significance.

The correlation analysis was significant for the first year only for accumulated rainfall in the months preceding the collection. The correlation was inversely proportional and occurs for 
the two fractions and for the litter total.

The annual contribution of litterfall varies depending on the interaction of biotic and abiotic factors in each ecosystem (Delarmelina, 2015). This author observed that the greatest litterfall coincides with the end of the dry period, a fact also observed by Pinto et al. (2008), Godinho et al. (2013), and reaffirmed in this study.

In a transitional region between the Amazonian biome and the Cerrado, in the municipality of Nova Xavantina MT, Peixoto et al. (2018) found a significant negative correlation between rainfall and litterfall. The authors evaluated rainfall in two different years and observed that the year with the lowest rainfall provided a significant increase.

Compared with previous studies (Godinho et al., 2013; Delarmelina, 2015), there is a reduction in the total amount of litter in the order of $38 \%$. In the first year of monitoring, $9268.54 \mathrm{~kg} \mathrm{ha}^{-1}$ of litter was quantified and only $5741.44 \mathrm{~kg} \mathrm{ha}^{-1}$ in the second year. This variation in litter input is expected within the same forest formation, as there is variation in the conditions of each site (Pezzato et al., 2006; Pinto et al., 2008; Pimenta et al., 2011). However, this reduction occurred at the same site and must be associated with environmental disturbances that have occurred over time (Sato et al., 2010). Precipitation may be the main cause of variation in the input. During the study by Godinho et al. (2013), the accumulated rainfall in the year was $1267 \mathrm{~mm}$, while in this study it was $771 \mathrm{~mm}$ and $940 \mathrm{~mm}$ in the first and second year, representing reductions of $39.1 \%$ and $25.8 \%$, respectively.

In the studies by Godinho et al. (2013) and Delarmelina (2015), no significant correlation was observed between litter input and the climatic elements' temperature and precipitation. However, according to Arato et al. (2003), there is a delay in the response of vegetation to climatic elements and water stress, indicating that litter deposition does not have an immediate cause/effect relationship with precipitation. This delay in the response of litter input was found by Scoriza and Piña-Rodrigues (2014), who observed a significant correlation between the total input and the rainfall that occurred in the months before collection, in a fragment of Semideciduous Seasonal Forest. Thus, the correlation between the litter input and the accumulated precipitation in periods before the litter input allows us to infer that this correlation also occurs over the years according to the annual water regime.

The correlation of total litter with precipitation was also evidenced for leaves. Since this is the most representative fraction (Schumacher et al., 2011), its contribution pattern should be associated with the pattern of total litter, a fact observed in this study and in other works (Vendrami et al., 2012; Scoriza and Piña -Rodrigues, 2014). In a work carried out by Godinho et al. (2013), the authors observed a high correlation between the contribution of the leaf fraction and the total litter input, demonstrating the possibility of using this fraction as an indicator of litter production in forest ecosystems.

The variation in the amount of twigs + miscellaneous fractions between years is attributed to twigs because miscellaneous has low representation in the total litter input (Delarmelina, 2015). According to Pinto et al. (2008), the deposition of the twig fractions may occur in response to biotic factors, with a delayed effect over time, generating a deposition pattern marked by temporal heterogeneity.

\subsection{Chemical composition of litterfall}

As shown in Figure 4, some nutrients showed statistically significant differences in concentrations over the seasons. In general, the winter seasons registered lower concentrations of nutrients. The statistical difference was significant in potassium, calcium and magnesium. A possible explanation for this fact is associated with the long period with rainfall around $31.8 \%$ below the historical average. This may be developing hydric stress to the vegetation and, consequently, less translocation of photoassimilates, thus requiring their translocation from mature plant tissues to younger tissues. 
According to McCree and Fernández (1989) and Taiz and Zeiger (1991), the response of plants to water deficit consists of decreasing leaf area production, closing the stomata, increasing leaf senescence and abscission. Water deficit increases leaf senescence (Wright $e t$ $a l ., 1983)$, because dry soil cannot provide necessary nitrogen to supply crop growth. Therefore, the nitrogen from the interior of the plant is translocated from the more mature leaves to the growing tissues.
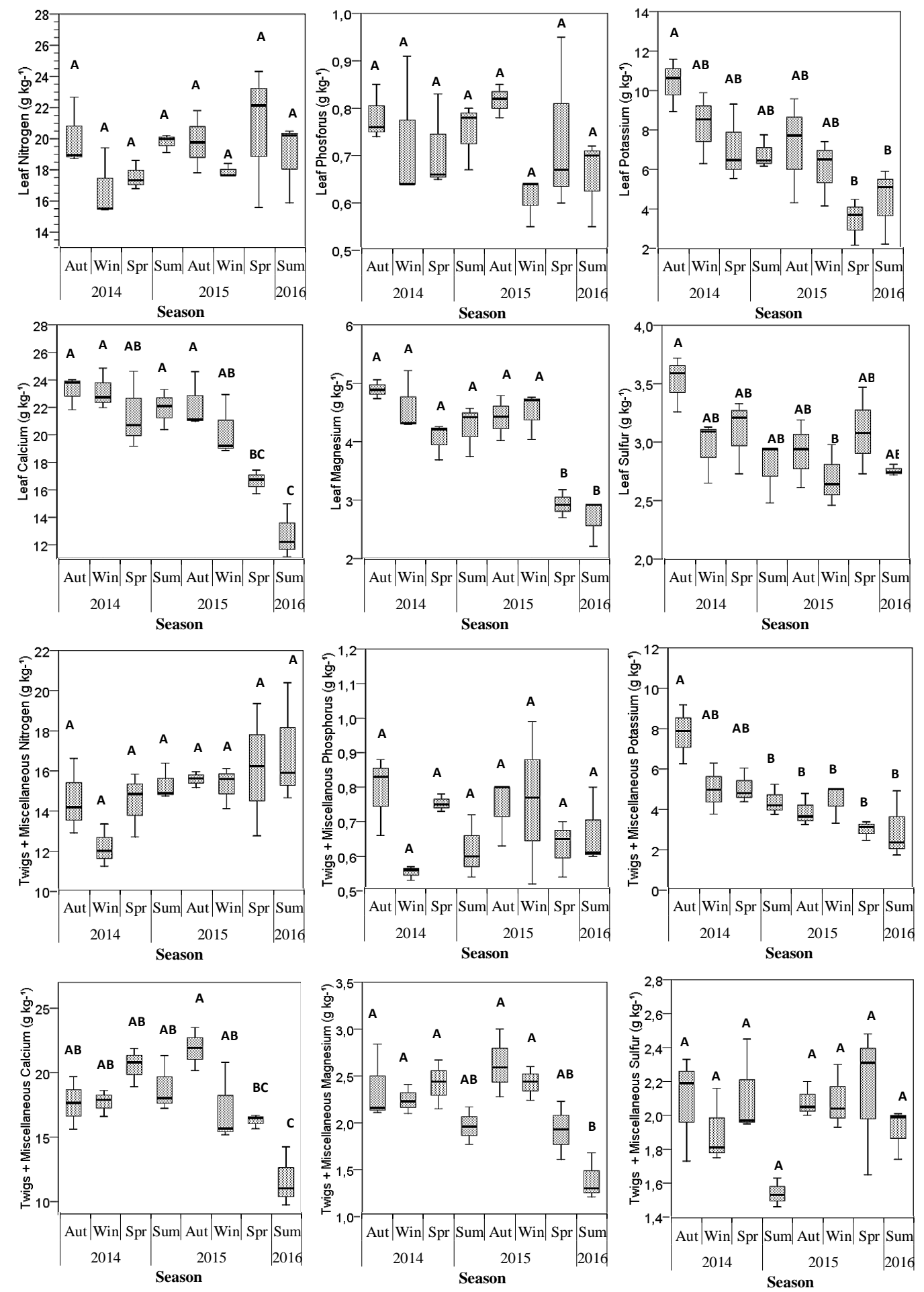

Figure 4. Seasonality of nutrient concentration in leaves and twigs + miscellaneous fractions, in an Atlantic forest fragment over two years.

Different letters between seasons represent a statistical difference $(p<0.05)$. 
The macronutrient content in litterfall over the two years shows that the seasons with the highest nutrient input coincide with the seasons with the highest litter amounts, Figure 5. Following this pattern, the nutrient inputs from the first 4 seasons provided the highest amounts of all macronutrients when compared to the subsequent 4 seasons. A total of $403 \mathrm{~kg} \mathrm{ha}^{-1}$ of macronutrients were input in the first 4 seasons against only $269 \mathrm{~kg} \mathrm{ha}^{-1}$ in the 4 subsequent seasons. This provides a difference of $133.82 \mathrm{~kg} \mathrm{ha}^{-1}$, or $33.2 \%$ of the second period compared to the first. The order of macronutrient content of the litter input was $\mathrm{Ca}>\mathrm{N}>\mathrm{K}>\mathrm{Mg}>\mathrm{S}>$ $\mathrm{P}$, for the two years.

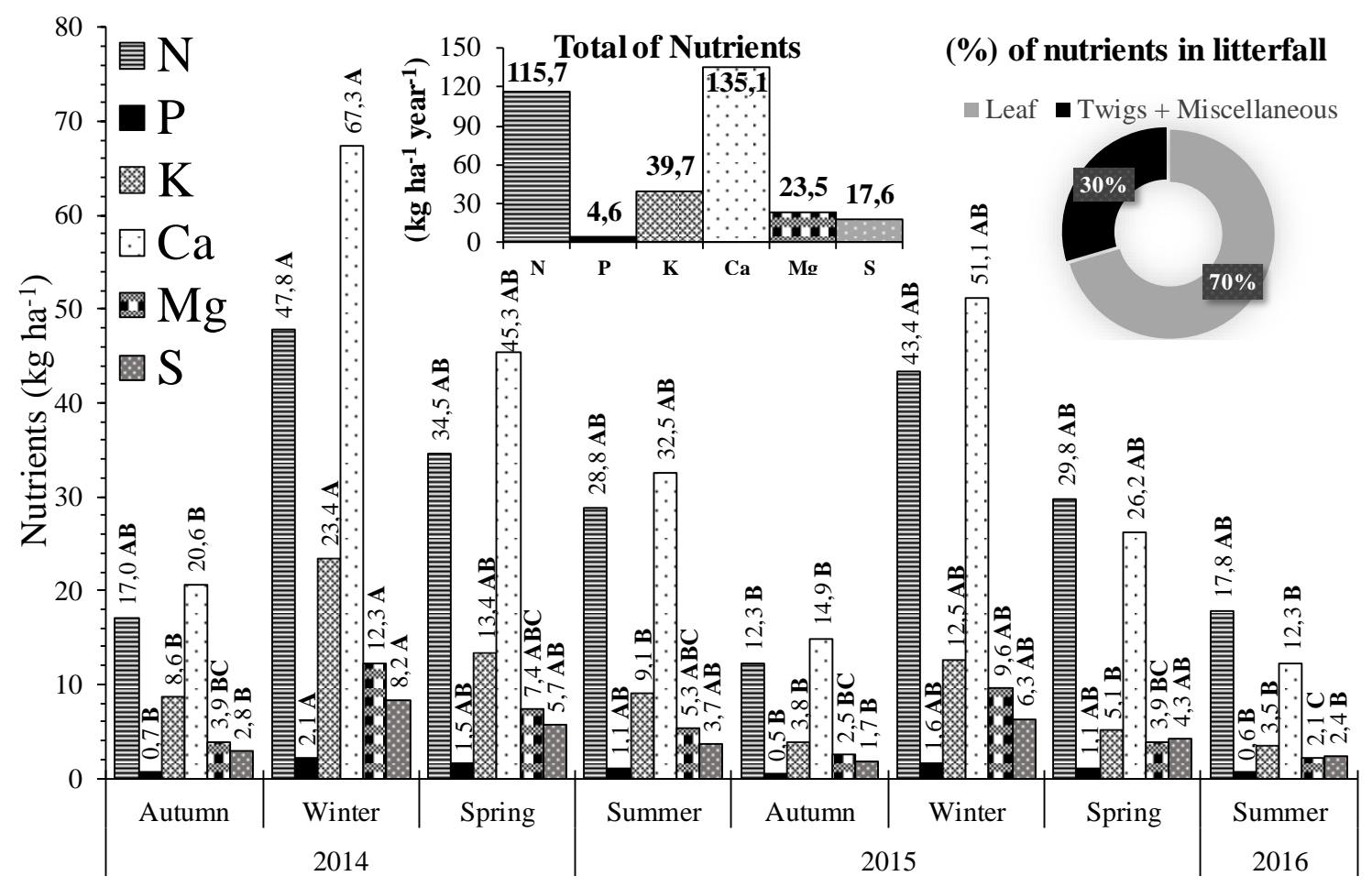

Figure 5. Annual and seasonal nutrients in litter fall over two years in an Atlantic Forest fragment located in southeastern Brazil.

Different letters between seasons for the same nutrient represent a statistical difference $(\mathrm{p}<0.05)$.

The monthly contribution of macronutrients via the leaf fraction had a pattern of variation similar to that provided by the total of the two fractions. The total content of macronutrients in the leaf fraction was 288.08 and $185.54 \mathrm{~kg} \mathrm{ha}^{-1 ;}$ that is, a reduction of $35.6 \%$ for year 1 and year 2 , respectively. In this fraction, the order of macronutrient content contributed via litter was the same as the total for year $1(\mathrm{Ca}>\mathrm{N}>\mathrm{K}>\mathrm{Mg}>\mathrm{S}>\mathrm{P})$, inverting Ca with $\mathrm{N}$ for year $2(\mathrm{~N}>\mathrm{Ca}$ $>\mathrm{K}>\mathrm{Mg}>\mathrm{S}>\mathrm{P}$ ).

In general, the leaf fractions presented a greater contribution to nutrient cycling, in relation to the twigs + miscellaneous fractions. The leaf fractions contributed 71.5 and $68.9 \%$ (year 1 and year 2) of the total macronutrient input.

The greatest contributions of macronutrients from the twigs + miscellaneous fractions were observed in the seasons with the greatest contribution of mass of these fractions. The respective fractions registered a reduction of $115 \mathrm{~kg} \mathrm{ha}^{-1}$ to $83.7 \mathrm{~kg} \mathrm{ha}^{-1}$ from year 1 to year 2 . This represents a decrease of $27.2 \%$. The order of macronutrient content in these fractions in the two years was the same as observed in the total input $(\mathrm{Ca}>\mathrm{N}>\mathrm{K}>\mathrm{Mg}>\mathrm{S}>\mathrm{P})$.

The fluctuation in the amount of litter influenced the contribution of macronutrients between seasons and years of study. This variation was also observed by Godinho et al. (2013) and by Delarmelina (2015), who found a greater input of nutrients in the months with the 
highest litter input, coinciding with the period with the highest leaf input, the fraction responsible for the largest amount of input nutrients. Comparing the results of these authors with the present study, it is possible to see that both the supply of nutrients and litter decreased over time.

In a tropical rainforest located in Central America, Panama, Sayer et al. (2020) found nutrient returns by litterfall of 191, 6.3, 59.5, 207 and $46.5 \mathrm{~kg} \mathrm{ha}^{-1}$ of $\mathrm{N}, \mathrm{P}, \mathrm{K} \mathrm{Ca}$ and $\mathrm{Mg}$, respectively. These quantities are higher than the values of the present study and can be explained by the stage of maturity of the forest, the type of denser forest formation and the more favorable climatic conditions. When compared with studies carried out in other tropical forests (Vital et al., 2004; Pinto et al., 2008), and with studies in the same area (Godinho et al., 2013; Delarmelina, 2015), it is possible to see that the contribution of N, P and Ca were lower in the two years, while $\mathrm{K}$ and $\mathrm{Mg}$ in year 1 were within the range of the studies cited, being below for year 2.

The greater amount of $\mathrm{Ca}$ in the litter input, when compared to the other macronutrients, it is due to the fact that it is a structural and non-soluble element, having low translocation capacity from mature to younger tissues (König et al., 2002; Schreeg et al., 2013). The low return of $\mathrm{P}$ is a reflection of the low natural fertility of tropical soils, such as the soil in the present study, and because this is a nutrient that has high redistribution in plant tissues. This is an adaptation of forest species in low fertility soils (Espig et al., 2009).

\subsection{Nutrient Use Efficiency}

The order of efficiency in the use of macronutrients according to the average of the years was: $\mathrm{P}>\mathrm{S}>\mathrm{Mg}>\mathrm{K}>\mathrm{N}>\mathrm{Ca}$, Table 1 . The efficiency in the use of macronutrients $\mathrm{P}, \mathrm{K}, \mathrm{Ca}$ and $\mathrm{Mg}$ increased from year 1 to year 2 in both fractions and the total amount of litter deposited. Contrary to these, the efficiency in the use of $\mathrm{N}$ decreased from the first to the second year, while the $S$ had an increase for the leaves and total fraction, and a reduction for the twigs + miscellaneous fraction.

Table 1. Use efficiency of macronutrients by leaf fractions, twigs and miscellaneous.

\begin{tabular}{cccccccc}
\hline Fraction & Year & $\mathbf{N}$ & $\mathbf{P}$ & $\mathbf{K}$ & $\mathbf{C a}$ & $\mathbf{M g}$ & $\mathbf{S}$ \\
\hline Leaf & & 56 & 1393 & 127 & 44 & 224 & 335 \\
Twig + miscellaneous & 1 & 73 & 1535 & 192 & 54 & 447 & 520 \\
Total & & 61 & 1439 & 144 & 47 & 271 & 382 \\
Leaf & & 52 & 1493 & 204 & 53 & 266 & 354 \\
Twig + miscellaneous & 2 & 63 & 1515 & 301 & 60 & 481 & 482 \\
Total & & 56 & 1501 & 230 & 55 & 316 & 391 \\
Leaf & & 54 & 1443 & 166 & 49 & 245 & 345 \\
Twig + miscellaneous & Average & 68 & 1525 & 247 & 57 & 464 & 501 \\
\hline Total & & 59 & 1470 & 187 & 51 & 294 & 387 \\
\hline
\end{tabular}

Year 1 = 2014-2015; Year $2=2015-2016$.

The increase observed in the efficiency of nutrient use from year 1 to year 2, except for $\mathrm{N}$, indicates that species are making savings in their use, indicating the possibility of restriction in the primary production of the environment (Vitousek, 1982). Considering the work of Godinho 
et al. (2013) as one extreme, and year 2 of the present study as the other extreme, there was an increase in nutrient use efficiency for $\mathrm{N}, \mathrm{P}, \mathrm{K}$ and $\mathrm{Ca}$, and a reduction for $\mathrm{Mg}$ and $\mathrm{S}$. This variation between different years can be compared with the decrease in the availability of these nutrients in the soil, as well as with the mortality and emergence of new individuals and species (Jacobson et al., 2011; Bündchen et al., 2013). According to these authors, forest species, due to their interspecific variation in nutrient content, are used differently, even in an environment with similar nutritional availability.

The high efficiency in the use of $\mathrm{P}$ is related to its low availability in tropical soils, which indicates it as a limiting element in plant growth (Rebeille et al., 1984; Laliberte et al., 2013). The low efficiency in the use of $\mathrm{N}$ and $\mathrm{Ca}$ is associated with the high concentrations of these macronutrients in plant tissues. $\mathrm{N}$ is mainly present in leaves, where it is present in chloroplasts as a constituent of the chlorophyll molecule, associated with efficiency in the use of photosynthetically active radiation (Hirose and Bazzaz, 1998).

\section{CONCLUSION}

Litterfall in an Atlantic Forest fragment showed seasonal behavior with an average annual production of $6.78 \mathrm{Mg} \mathrm{ha}^{-1}$. Although the leaf fraction represents $64.9 \%$ of the dry mass, it was responsible for $70.4 \%$ of the nutrients for the forest soil.

The variation in litter deposition occurs in response to the rainfall regime, mainly due to the accumulation over time, due to the non-immediate responses of the vegetation. This variation was determined by the leaf fractions, which constitute most of the plant material.

The increase in NUE nutrient-use efficiency in the second year compared to the first indicates that strategically plants may be translocating relative amounts of their nutrients under conditions of reduced rainfall. The two years with rainfall below the historical average must have caused less water availability in the soil for plant absorption; as a consequence, there is a reduction in the production of photoassimilates and nutrient transport by the xylem.

\section{ACKNOWLEDGEMENTS}

This study was financed in part by the Coordenação de Aperfeiçoamento de Pessoal de Nível Superior - Brasil (CAPES) - Finance Code 001.

\section{DATA AVAILABILITY STATEMENT}

The data that support the findings of this study are available on request from the corresponding author. The data are not publicly available due to privacy or ethical restrictions.

\section{REFERENCES}

ALVARES, C. A. et al. Köppen's climate classification map for Brazil. Meteorologische Zeitschrift, v. 22, n. 6, p. 711-728, 2014. https://doi.org/10.1127/0941-2948/2013/0507

ARCHANJO, K. M. P. A.; SILVA, G. F.; CHICHORRO, J. F.; SOARES, C. P. B. Estrutura do componente arbóreo da Reserva Particular do Patrimônio Natural Cafundó, Cachoeiro de Itapemirim, Espírito Santo, Brasil. Floresta, v. 42, n. 1, p. 145-160, 2012.

ARATO, H. D.; MARTINS, S. V.; FERRARI, S. H. S. Produção e decomposição da serrapilheira em um sistema agroflorestal implantado para recuperação de área degradada em Viçosa - MG. Revista Árvore, v. 27, n. 5, p. 715-721, 2003. 
BALIEIRO, F. C.; FRANCO, A. A.; PEREIRA, M. G.; CAMPELlO, E. F. C.; DIAS, L. E.; FARIA, S. M. et al. Dinâmica de serapilheira e transferência de nitrogênio ao solo em plantios de Pseudosamanea guachapele and Eucalyptus grandis. Pesquisa Agropecuária Brasileira, v. 39, n. 6, p. 597-601, 2004.

BELLO, C.; GALETTI, M.; PIZO, M. A.; MAGNAGO, L. F. S.; ROCHA, M. F.; LIMA, R. A. F. et al. Defaunation affects carbon storage in tropical forests. Science Advances, v. 1, n. 11, 2015. https://doi.org/10.1126/sciadv.1501105

BERG, B.; LASKOWSKI, R. Litter fall. In: BERG, B.; LASKOWSKI, R. Litter Decomposition: A Guide to Carbon and Nutrient Turnover. London: Elsevier Academic Press, 2005. https://doi.org/10.1016/ S0065-2504(05)38002-0

BÜNDCHEN, M.; BOEGER, M. R. T.; REISSMANN, C. B.; SILVA, S. L. C. da. Status Nutricional e eficiência no uso de nutrientes em espécies arbóreas da floresta subtropical no sul do Brasil. Scientia Forestalis, v. 41, n. 98, p. 227-236, 2013.

CALDEIRA, M. V. W.; VITORINO, M. D.; SCHAADT, S. S.; MORAES, E.; BALBINOT, R. Quantificação de serapilheira e de nutrientes em uma Floresta Ombrófila Densa. Semina: Ciências Agrárias, v. 29, n. 1, p. 53-68, 2008.

CASTRO, K. C. Serapilheira e estoque de carbono ao longo de um gradiente altitudinal na Floresta Ombrófila Densa, no Parque Nacional do Caparaó, ES. 2014. 99 f. Dissertação (Mestrado em Ciências Florestais) - Universidade Federal do Espírito Santo, Jerônimo Monteiro, 2014.

CHAVE, J.; NAVARRETE, D.; ALMEIDA, S.; ALVAREZ, E.; ARAGAO, L.; BONAL, D. et al. Regional and seasonal patterns of litterfall in tropical South America. Biogeosciences, v. 7, p. 43-55, 2010. https://doi.org/10.5194/ bg-7-43-2010

CUEVAS, E.; MEDINA, E. Nutrient dynamics within Amazonian Forest ecosystems. Oecologia, v. 68, p. 466-472, 1986.

DELARMELINA, W. M. Fertilidade, estoque de carbono orgânico do solo e serapilheira em uma Floresta Estacional Semidecidual Submontana. 2015. 123 f. Dissertação (Mestrado em Ciências Florestais) - Universidade Federal do Espírito Santo, Jerônimo Monteiro, 2015.

EMBRAPA. Manual de métodos de análise de solos. 2. ed. Rio de Janeiro: Embrapa Solos, 2011.

ESPIG, S. A.; FREIRE, F. J.; MARANGON, L. C.; FERREIRA, R. L. C.; FREIRE, M. B. G. S.; ESPIG, D. B. Sazonalidade, composição e aporte de nutrientes da serapilheira em fragmento de Mata Atlântica. Revista Árvore, v. 33, n. 5, p. 949-956, 2009.

FAHRIG. L. Effects of habitat fragmentation on biodiversity. Annual Review of Ecology, $\begin{array}{llllll}\text { Evolution and } & \text { Systematics, } & \text { v. 34, p. 487-515. }\end{array}$ https://doi.org/10.1146/annurev.ecolsys.34.011802.132419

FASSEBENDER, H. W. Modelos edafológicos de sistemas agroforestales. 2. ed. Turrialba: CATIE, 1993. $491 \mathrm{p}$.

FUNDAÇÃO SOS MATA ATLÂNTICA. Atlas dos Remanescentes Florestais da Mata Atlântica - Período 2018-2019. 2020. Available: http://mapas.sosma.org.br. Access: 23 June 2021. 
GODINHO, T. de O.; CALDEIRA, M. V. W.; CALIMAN, J. P.; PREZOTTI, L. C.; WATZLAWICK, L. F.; AZEVEDO, H. C. A. et al. Biomassa, macronutrientes e carbono orgânico na serapilheira depositada em trecho de floresta Estacional Semidecidual Submontana, ES. Scientia Forestalis, v. 41, p. 131-144, 2013.

HAAG, H. P. Ciclagem de nutrientes em florestas tropicais. São Paulo: Fundação Cargill, 1985. 144p.

HIROSE, T.; BAZZAZ, F. A. Trade-off between light and nitrogen-use efficiency in canopy photosynthesis. Annals of Botany, v. 82, n. 2, p. 195-202, 1998.

IBAMA. Portaria 62, de 19 de maio de 1998. Reconhece mediante registro, como reserva particular do patrimônio natural a área de 517,00 hectares, constituindo-se parte integrante do imóvel Fazenda Cafundó, denominado reserva Fazenda Boa Esperança, situado no município de Cachoeiro de Itapemirim/ES. Diário Oficial [da] União, seção 1, Brasília, DF, p. 105, 20 maio 1998.

INCAPER. Assistência técnica e extensão rural. 2017. Available: http://hidrometeorologia.incaper.es.gov.br/?pagina=atlas_pluvio. Access: 19 Jan. 2017.

IBGE. Manual Técnico da Vegetação Brasileira. 2. ed. Rio de Janeiro, 2012. 271 p.

JACOBSON, T. K. B.; BUSTAMANTE, M. M. da C.; KOZOVITS, A. R. Diversity of shrub tree layer, leaf litter decomposition and $\mathrm{N}$ release in a Brazilian Cerrado under $\mathrm{N}, \mathrm{P}$ and N plus additions. Environmental Pollution, v. 159, n. 10, p. 2236-2242, 2011.

KÖNIG, F. G.; SCHUMACHER, M. V.; BRUN, E. J.; SELING, I. Devolução de nutrientes via serapilheira em um fragmento de Floresta Estacional Decidual no município de Santa Maria, RS. Brasil Florestal, v. 72, p. 45-52, 2002.

KRAMER, J. P.; KOZLOWSKI, T. Fisiologia das Árvores. Lisboa: Fundação Calouste Gulbekian, 1960. 745 p.

LALIBERTE, E.; GRACE, J. B.; HUSTON, M. A.; LAMBERS, H.; TESTE, F. P.; TURNER, B. L. et al. How does pedogenesis drive plant diversity? Trends in Ecology \& Evolution, v. 28, p. 331-340, 2013.

LAWRENCE, D. Regional-Scale Variation in Litter Production and Seasonality in Tropical Dry Forests of Southern Mexico. Biotropica, v. 37, n. 4, p. 561-570. 2005. https://doi.org/10.1111/j.1744- 7429.2005.00073.x

MALHI, Y.; DOUGHTY, C.; GALBRAITH, D. The allocation of ecosystem net primary productivity in tropical forests. Philosophical Transactions of the Royal Society B: Biological Sciences, v. 366, p. 3225- 3245. 2011. https://doi.org/10.1098/rstb.2011.0062

MARTINS, S. V. Recuperação de áreas degradadas: ações em áreas de preservação permanente, voçorocas, taludes rodoviários e mineração. Viçosa: Aprenda Fácil, 2016. 270 p.

MARTINS, S. V.; MIRANDA NETO, A.; RIBEIRO, T. M. Uma abordagem sobre diversidade e técnicas de restauração ecológica. In: MARTINS, S. V. Restauração ecológica de ecossistemas degradados. Viçosa: UFV, 2012. 293 p.

McCREE, K. J.; FERNÁNDEZ, C. J. Simulation model for studying physiological water stress responses of whole plants. Crop Science, v.29, p. 353-360, 1989. 
NEPSTAD, D.; MOUTINHO, P.; DIAS-FILHO, M.; DAVIDSON, E.; CARDINOT, G.; MARKEWITZ, D. et al. The effects of partial throughfall exclusion on canopy processes, aboveground production, and biogeochemistry of an Amazon forest. Journal of Geophysical Research: Atmospheres, v. 10, n. 7, p. 1-18, 2002. https://doi:10.1029/2001JD000360

ODUM, E. P. The strategy of ecosystem development. Science, v. 164, p. 262-270, 1988.

OLIVEIRA, R. R.; LACERDA, L.D. Produção de serapilheira em estágios sucessionais de Floresta Atlântica na Ilha Grande, RJ. Revista Brasileira de Botânica, v. 28, n. 1, p. 93 99. 1999.

PEIXOTO, K. S.; MARIMON-JUNIOR, B. H.; CAVALHEIRO, K. A. et al. Assessing the effects of rainfall reduction on litterfall and the litter layer in phyto physiognomies of the Amazonia-Cerrado transition. Brazilian Journal of Botany, v. 41, p. 589-600, 2018.

PEZZATO, A. W.; WISNIEWSKI, C. Produção de serapilheira em diferentes seres sucessionais da Floresta Estacional Semidecidual no oeste do Paraná. Floresta, v. 36, n. 1, p. 111-120, 2006.

PEZZOPANE, J. E. M.; CASTRO, F. S.; PEZZOPANE, J. R. M.; CECÍliO, R. A. Agrometeorologia: aplicações para o Espírito Santo. Alegre: UFES, 2012. 178p.

PINTO, S. I. DO C.; MARTINS, S. V.; BARROS, N. F. DE; CARLOS, H.; DIAS, T. Produção de serapilheira em dois estádios sucessionais de floresta estacional semidecidual na reserva mata do paraíso, em Viçosa, MG. Revista Árvore, v. 32, n. 3, p. 545-556, 2008.

PIMENTA, J. A.; ROSSI, L. B.; TOREZAN, J. M. D.; CAVALHEIRO, A. L.; BIANCHINI, E. Produção de serapilheira e ciclagem de nutrientes de um reflorestamento e de uma Floresta Estacional Semidecidual no sul do Brasil. Acta Botânica Brasílica, v. 25, n. 1, p. 53-57, 2011.

R CORE TEAM. R: A Language and Environment for Statistical Computing. Vienna, 2016.

REBEILLE, F.; BLIGNY, R.; DOUCE, R. Is the cytosolic Pi concentration a limiting factor for plant cell respiration? Plant Physiology, v. 74, p. 355-359, 1984.

SANCHEZ, G.; ALVAREZ-SANCHEZ, J. Litterfall in primary and secondary tropical forests of Mexico. Tropical Ecology, v. 36, n. 2, p. 191-220, 1995.

SATO, T.; KOMINAMI, Y.; SAITO, S.; NIIYAMA, K.; TANOUCHI, H.; NAGAMATSU, D. et al. Temporal dynamics and resilience of fine litterfall in relation to typhoon disturbances over 14 years in an old-growth lucidophyllous Forest in southwestern Japan. Plant Ecology, n. 208, p. 187-198, 2010.

SAYER, E. J. et al. Revisiting nutrient cycling by litterfall - Insights from 15 years of litter manipulation in old-growth lowland tropical forest. Advances in Ecological Research, 2020. https://doi.org/10.1016/bs.aecr.2020.01.002

SCHREEG, L.A.; MACK, M. C.; TURNER, B. L. Leaf litter inputs decrease phosphate sorption in a strongly weathered tropical soil over two time scales. Biogeochemistry, $\mathrm{v}$. 113, p. 507-524, 2013. 
SCHUMACHER, M. V.; TRÜBY, P.; MARAFIGA, J. M.; VIERA, M.; SZYMCZAK, D. A. Espécies predominantes na deposição de serapilheira em fragmento de Floresta Estacional Decidual no Rio Grande do Sul. Ciência Florestal, v. 21, n. 3, p. 479-486, 2011.

SCORIZA, R. N.; PIÑA-RODRIGUES, F. C. M. Influência da precipitação e temperatura do ar na produção de serapilheira em trecho de Floresta Estacional em Sorocaba, SP. Floresta, v. 44, n. 4, p. 687-696, 2014.

SCORIZA, R. N.; PEREIRA, M. G.; PEREIRA, G. H. A.; MACHADO, D. L.; SILVA, E. M. R. da. Métodos para coleta e análise de serapilheira aplicados à ciclagem de nutrientes. Floresta e Ambiente, v. 2, n. 2, p. 01-18, 2012.

STRASSBURG, B. B. N.; IRIBARREM, A.; BEYER, H. L. et al. Global priority areas for ecosystem restoration. Nature, v. 586, p. $724-729,2020$. https://doi.org/10.1038/s41586-020-2784-9

TAIZ, L.; ZEIGER. Plant Physiology. Redwood City: The Benjamim/ Cummings Publishing Company, 1991.

TEDESCO, M. J.; GIANELLO, C.; BISSANI, C. A.; BOHNEN, H.; VOLKWEIS, S. J. Análise de solo, plantas e outros materiais. 2. ed. Porto alegre: UFRS, 1995. 174p.

VENDRAMI, J. P.; JURINITZ, C. F.; CASTANHO, C. T. Litterfall and leaf decomposition in forest fragments under different successional phases on the Atlantic Plateau of the state of Sao Paulo, Brazil. Biota Neotropica, v. 12, n. 3, p. 136 - 143, 2012.

VITAL, A. R. T.; GUERRINI, I. A.; FRANKEN, W. K.; FONSECA, R. C. B. Produção de serapilheira e ciclagem de nutrientes de uma floresta estacional semidecidual em zona ripária. Revista Árvore, v. 28, n. 6, p. 793-800, 2004.

VITOUSEK, P. M. Nutrient cycling and nutrient use efficiency. American Naturalist, v. 119, n. 4, p. 553-72, 1982.

WAGNER, F. H. et al. Climate seasonality limits leaf carbon assimilation and wood productivity in tropical forests. Biogeosciences, v. 13, n. 8, 2016. https://doi.org/10.5194/bg-13-2537-2016

WANG, C. G.; ZHENG, X. B.; WANG, A. Z.; DAI, G. H.; ZHU, B. K.; ZHAO, Y. M. et al. Temperature and precipitation diversely control seasonal and annual dynamics of litterfall in a temperate mixed mature forest, revealed by long-term data analysis. Journal of Geophysical Research: Biogeosciences, v. 126, n. e2020JG006204, 2021. https://doi.org/10.1029/2020JG006204

WOLF, A.; DOUGHTY, C. E.; MALHI, Y. Lateral Diffusion of Nutrients by Mammalian Herbivores in Terrestrial Ecosystems. PLoS ONE, v. 8, n. 8, p. 1-10. 2013. https://doi.org/10.1371/journal.pone.0071352

WRIGHT, G. C.; SMITH, R. G.; McWILLIAM, J. R. Differences between two grain sorghum genotypes in adaptation to drought stress. I. Crop growth rate and yield response. Australian Journal of Agricultural Research, v. 34, p. 615- 626, 1983.

ZHANG, H.; YUAN, W.; DONG, W.; LIU, S. Seasonal patterns of litterfall in forest ecosystem $\begin{array}{llllll}\text { worldwide. Ecological Complexity, v. 20, p. 240-247, } 2014 . & \end{array}$ https://doi.org/10.1016/j.ecocom.2014.01.003 